\title{
Tax structure and economic growth: a study of selected Indian states
}

\author{
Yadawananda Neog ${ }^{*}$ (D) and Achal Kumar Gaur
}

*Correspondence:

yadawananda.neog3@bhu. ac.in; yadavneog@gmail.com Department of Economics, Banaras Hindu University, Varanasi, India

\begin{abstract}
The present study examines the long-run and short-run relationship between tax structure and state-level growth performance in India for the period 1991-2016. The analysis in this paper is based on the model of Acosta-Ormaechea and Yoo (2012), and for the verification of the relationship between taxation and economic growth the panel regression method is used. With the use of 14 Indian states data, Panel Pool mean group estimation indicates that income tax and commodity-service tax have negative effects whilst property and capital transaction tax have a significant positive effect on state economic growth. This study finds ' $U$ ' shape relationship between tax structure and growth performance. Based on the analysis, we conclude that for faster growth of Indian states, policymakers should give more focus on property taxes along with the reduction in income taxes.
\end{abstract}

Keywords: Tax structure, Growth, Pool mean group, India

\section{Introduction}

The study on the potential association between tax structure and growth performance has gathered a great deal of attention from policymakers, academicians and regulatory circles for several reasons. First, the developing and emerging economies require a large volume of tax revenues for the smooth and efficient functioning of the state at both the national and sub-national levels. Globalization has laid down the foundation for Goods and Service Tax (GST) in many developing countries (Mcnabb 2018). Due to competition, developing countries are also facing the difficulties to maintain existing tax revenues (Bird and Zolt 2011). Second, tax collection and structure of it create distortionary impacts in the economy through tax burden. Thus, the positive and negative impact of tax made the 'tax-growth' relationship more complex and the structure of taxation has a definite role in the development process of an economy.

In a budget constraint economy like India, investigation of tax-growth relationship enables us to formulate the suitable policy measure for the more inclusive and equitable growth process. The budget crisis is usually resolved through the cut-down of public spending or/and an increase in tax revenues (Macek 2014). Rapid reduction in spending or increase in taxes is harmful to long-run growth performance. Thus, the concern of the

(c) The Author(s) 2020. This article is licensed under a Creative Commons Attribution 4.0 International License, which permits use, sharing adaptation, distribution and reproduction in any medium or format, as long as you give appropriate credit to the original author(s) and the source, provide a link to the Creative Commons licence, and indicate if changes were made. The images or other third party material in this article are included in the article's Creative Commons licence, unless indicated otherwise in a credit line to the material. If material is not included in the article's Creative Commons licence and your intended use is not permitted by statutory regulation or exceeds the permitted use, you will need to obtain permission directly from the copyright holder. To view a copy of this licence, visit http://creativeco mmons.org/licenses/by/4.0/ 
government lies with the problem of fiscal consolidation with sustainable growth performance where tax policies are vital.

Empirical evidence on the impact of tax structure on growth performance is not conclusive. India has adopted the Goods and Service Tax (GST) policy in 2017 intending to raise indirect tax collections and transform the indirect tax structure into a single market to avoid tax evasions and double taxation. GST is regarded as one of the major tax policy changes in independent India and economists are an optimist about its impact on revenue generations and growth performance. But this policy is not the only policy that shaped in independent India; other major policy changes also take place after independence. ${ }^{1}$ Tax Reform Committee (TRC) report of 1991 regarded one of the productive and structured policy recommendations in the recent decade. At the state level, sales tax reform in the form of Value Added Tax (VAT) in 2005 becomes a fruitful policy initiative. However, the tax collections in both national and sub-national level are still low as compared to the international standards. Changes in tax policy also change in the tax structure in the economy and India witnessed these changes at both levels of governments. Recent studies proved that the changes in tax structure have decisive implication in the growth performance through work-leisure behaviour, investment decisions and overall productivity (Arnold et al. 2011; Gemmell et al. 2011; Macek 2014; Mdanat et al. 2018; Durusu-Ciftci 2018). In India, very few empirical studies are available which analyse the impact of these changes in tax structure on growth performance and this study will be first to investigate tax-growth nexus in India with the use of state-level data.

This analysis primarily concerned with tax structure rather than to tax levels (usually measured as a tax-GDP ratio). The main advantage of tax structure analysis is that it provides revenue-neutral tax policy changes which remove the difficulties related with the question of how aggregate tax revenue changes relates with expenditure changes (Arnold et al. 2011). The empirical results from linear panel regression suggest us that property and capital transection tax are positively affecting the state's growth performance, where commodity and service tax effect negatively. However, the non-linear panel regression indicates that the positive effect is only visible for property taxes at a higher level where the negative effect of commodity and service taxes becomes positive after a threshold point. The effect of income tax is not significant in long run irrespective of panel regression models.

The structure of the paper is as follows: Sect. 2 deals with the theoretical framework and empirical literature, followed by a brief description of data and methodology in Sect. 3. Empirical results and discussion are presented in Sect. 4 and our last Sect. 5 is for conclusions and recommendations.

\section{Theoretical framework and empirical literature}

Growth literature very recently acknowledges the role of taxation in the growth process of an economy. Until recently, growth models are more concerned with the steadystate process and exogenous changes. On the theoretical ground, taxation does not have any impact on growth (Myles 2000). Development of endogenous growth models 
creates the space for fiscal policy especially tax policy in determining the growth performance. Barro (1990), King and Rebello (1990) and Jones et al. (1993) were the pioneer in this regard. Tax level and tax structure have an impact on the saving behaviour of the household and investment in human capital. On the other hand, the firm also changes its investment decisions and innovations following tax policies (Johansson et al. 2008). These decisions and incentives in the accumulation of physical and human capital create the 'Growth' disparities amongst the countries and state economies.

A large body of literature available on "Tax-Growth" relationship is mostly dedicated to cross-country settings (Martin and Fardmanesh 1990; Karras 1999; Myles 2000; Tosun and Abizadeh 2005; Johansson et al. 2008; Vartia et al. 2008; Arnold 2011; Szarowska 2013; Macek 2014; Stoilova 2017; Safi et al. 2017; Durusu-Ciftci 2018) that investigates the effect of tax policy on economic performance. Income and corporation taxes are the major tax instruments for the governments irrespective of the level of developments of a country. The formation of tax structure with these two taxes has many implications in the growth performance. The study made by Arnold et al. (2011), Macek (2014) and Dackehag and Hansson (2012) has explored the negative relation of income and corporation tax with growth performance. Vartia et al. (2008) find the negative impact of corporation tax for OECD countries. If we consider the average and marginal tax rate, marginal tax is very influential than to average tax rate in investment decisions and labour supply. Empirical studies prove that marginal tax has a negative relation with growth, which indicate raising of marginal tax rate is associated with compromises with growth performance (Padovano and Galli 2001; Lee and Gordon 2005; Poulson and Kaplani 2008). Studies also established that other type of taxes also has a significant impact on growth performance, like consumption tax (Johansson et al. 2008; Durusu-Ciftci 2018), GST and Payroll (Tosun and Abizadeh 2005), property tax (Xing 2011), labour tax (Szarowska 2014), sales tax (Ojede and Yamarik 2012), excise (Reynolds 2006), etc.

However, looking at the single country's perspective, we find very little evidence on the same. Stockey and Rebelo (1995) with the use of the endogenous growth model study the role of tax reforms on U.S. growth performance. They have found that tax reforms have very minor implication with economic outcomes. There are several studies exist for US economy where they empirically try to establish the link between tax and growth. Atems (2015) finds the spatial spillover effect of income taxes on the growth of 48 contiguous states. On the other hand, Ojede and Yamarik (2012) have not found any kind of impact of income taxes on growth in these states. Their panel pool mean group estimation indicates that property and sales tax has detrimental consequences in development. With the use of data for the U.S. covering the period of 1912-2006, Barro and Redlick (2009) find that average marginal income taxes were halting the economic growth. However, they have provided an interesting argument that in wartime, the tax does not have any kind of relation with growth. In search of an answer to the question that whether corporate tax rise destroys jobs in the U.S., Ljungqvist and Smolyansky (2016) use firmlevel data for the period 1970-2010. The main conclusion of the paper is that a rise in corporate tax is not good for employment and income and has very little impact on economic activity. Using the error correction model, Mdanat et al. (2018) find for Jordan that income tax, corporation tax and personal tax negatively impact the growth. They 
suggest that irrespective of tax collection, the prime focus of the government should be social justice of the people. Dladla and Khobai (2018) also find similar results for South Africa where income taxes are coming out to be negative. For the case of Italy, Federici and Parisi (2015) used the 880 firms' data and results show that corporation tax is bad for investments with the consideration of both effective average and marginal taxes rates.

Looking at the literature, the empirical relationship of tax structure with growth performance is still unclear for India. This study attempts to fill the gap by examining the effect of tax policy on economic performance in an emerging economy such as India at the state level. Second, with the use of panel Pool Mean Group (PMG) estimator which assumes slope homogeneity in the long run and heterogeneity in the short run, we can incorporate the dynamic behaviour of the variables which will be new to tax structuregrowth study in India. Third, the tax-growth nexus may show a non-linear relationship due to the threshold effect. We consider this non-linearity in our panel regression model which will be a contribution to the existing literature.

\section{Data and methodology}

To study the effect of tax policy on economic performance in India, we employed three models and included each tax instruments in the models separately to avoid the problem of Multicollinearity. Following the works of Arnold et al. (2011) and Acosta-Ormaechea and Yoo (2012), the tax structure is measured by the share of individual tax to the total state tax revenues. We investigate the tax-growth relationship with the following equation.

$$
\operatorname{Ln}\left(Y_{\mathrm{it}}\right)=\alpha_{0}+\alpha_{1} \ln \left(\mathrm{SGI}_{\mathrm{it}}\right)+\alpha_{2} \ln \left(\mathrm{TAX}_{\mathrm{it}}\right)+\alpha_{3} \ln \left(\mathrm{Tax}^{\mathrm{Burden}}{ }_{\mathrm{it}}\right)+\epsilon_{\mathrm{it}}
$$

Here, $Y_{\text {it }}$ is the growth rate of Per capita net state domestic product (NSDP), SGI is the state gross investment as a percentage of state domestic product, TAX is one of the tax shares (Property, Commodity \& Services and Income), Tax Burden ${ }^{2}$ is the ratio of total tax revenues to state domestic product and $\epsilon$ is the error term. Per the work of AcostaOrmaechea and Yoo (2012), this study is more concerned with the impact of tax structure on growth rate rather than level effect. In model 1, we include property tax share, and in model 2 and model 3, we incorporate commodity \& service tax and income tax, respectively. By following the approach of Arnold et al. (2011), we include total tax burden as a control variable which will reduce the biases that may occur from correlation in between tax mix and tax burden. We also included Secondary Enrollment Rate as a proxy variable for human capital in our model, but the inconsistent and insignificant results make us drop the variable from the final estimation model.

In search of a possible non-linear relationship, we introduce a separate panel regression by introducing the square of each tax share into the models.

$$
\operatorname{Ln}\left(Y_{\mathrm{it}}\right)=\alpha_{0}+\alpha_{1} \ln \left(\mathrm{SGI}_{\mathrm{it}}\right)+\alpha_{2} \ln \left(\mathrm{TAX}_{\mathrm{it}}\right)+\alpha_{3} \ln \left(\mathrm{TAX}_{\mathrm{it}}\right)^{2}+\alpha_{4} \ln \left(\mathrm{Tax}_{\mathrm{Burden}}\right)+\epsilon_{\mathrm{it}}
$$

\footnotetext{
${ }^{2}$ This is the proxy for total tax burden in the economy with certain limitations. It does not include informal economy and expenditure policies.
} 
If the coefficient of $\alpha_{3}$ significant and carries an opposite sign to $\alpha_{2}$, then we can conclude that there is a non-linear relationship exist.

In this study, we included 14 Indian states for the period 1991 to 2016 and excluded North-Eastern states due to their relatively small tax revenue collections. Data have been taken from the Centre for Monitoring Indian Economy (CMIE) and Handbook of Statistics on the Indian States, published by Reserve Bank of India. The states that are included in this study are Andhra Pradesh (undivided), ${ }^{3}$ Assam, Gujarat, Haryana, Himachal Pradesh, Jammu \& Kashmir, Karnataka, Kerala, Maharashtra, Punjab, Tamil Nadu, Orissa, Rajasthan and West Bengal. All the states are included in model 1 and model 2. For model 3, due to the data availability, we include only seven states ${ }^{4}$ namely Andhra Pradesh, Assam, Gujarat, Karnataka, Kerala, Maharashtra, and West Bengal.

The selection of the study period is primarily driven by the argument provided by Rao and Rao (2006) that after the market-oriented economic reform of 1991, more systematic and long-term goal-oriented tax reforms were initiated in state level for India. The economic reform also brings rapid growth in India and it becomes very interesting to look at the tax-growth nexus after the economic reform. The second restriction related to the use of long data span is the availability of data for each tax head for each of the states under this study.

\subsection{Unit root}

Pool Mean Group (PMG) specification is very fruitful and widely used model to capture the dynamic behaviour of policy variables. This model is very powerful as it can investigate both I (0) and I (1) variables in a single autoregressive distributive lag (ARDL) model setup. A necessary condition in the ARDL model is that the model cannot deal with the I(2) variables. Thus, the investigation of stationarity becomes a compulsion. We used popular panel unit root tests like LLC (Levin et al. 2002), the IPS (Im et al. 2003), the ADF-Fisher Chi square (Maddala and Wu 1999) and PP-Fisher Chi square (Choi 2001) in this study.

\subsection{Panel PMG model}

The Mean Group (MG) estimator was developed by Pesaran and Smith (1995) to solve the issue of bias related to heterogeneous slopes in dynamic panels. Traditional panel models like instrumental variables' estimator of Anderson and Hsiao $(1981,1982)$ and Arellano and Bond (1991) may produce inconsistent results in a dynamic panel framework (Pesaran et al. 1999). MG estimator takes the average value of every cross-section and provides the long-run estimate for ARDL or PMG. On the other hand, Pooled Mean Group (PMG) estimator developed by Pesaran et al. (1999) assumes slope homogeneity in the long run but heterogeneous slopes in the short run for cross-section units. Dynamic Fixed Effect (DFE) also works like PMG and restricts cointegrating vector to be equal across all panels and restricts the speed of adjustment to be equal.

\footnotetext{
3 Telangana state was established in 2014. We merged the data of Andhra Pradesh and Telangana to achieve aggregate data for undivided Andhra Pradesh.

${ }^{4}$ Data for Income tax are available for ten states, but inclusion of these states made the model inconsistent due to huge fluctuations in tax revenue collections.
} 
Under these assumptions, PMG is more efficient estimator than to MG and DFE estimator. The prime requirement for PMG estimator is that $\mathrm{T}$ should be sufficiently large to N. Panel ARDL or PMG works through maximum likelihood. Our basic PMG begins with the following equation.

$$
Y_{\mathrm{it}}=\sum_{j=1}^{p} \delta_{i j, Y_{i}, i-j}+\sum_{j=0}^{q} \gamma_{i j x_{i, t-j}}+\mu_{i}+\varepsilon_{\mathrm{it}}
$$

Here, $x_{\mathrm{it}}$ is the vector explanatory variables and $y_{\mathrm{i}}$ is the lag dependent variable. $X_{\mathrm{it}}$ allows the inclusion of both I (0) and I (1) variables. State fixed effect is captured through $\mu_{\mathrm{i}}$. Above equation can be re-parameterized to ARDL format.

$$
\Delta y_{i t}=\sum_{j=i}^{p-1} \alpha_{i j} \Delta y_{i, t-j}+\sum_{j=0}^{q-1} \theta_{i j} \Delta x_{i, t-j}+\Phi_{i}\left[y_{i, t-1}-\beta_{i} x_{i t}\right]+\mu_{i}+\varepsilon_{i t}
$$

$\phi_{\mathrm{i}}$ measures the state-specific speed of adjustment and known as Error Correction Term. $\mathrm{B}_{\mathrm{i}}$ is the vector of long-run relationships and $\alpha_{\mathrm{ij}}$ and $\theta_{\mathrm{ij}}$ are the vectors of shortrun dynamic relationships. Pesaran et al. (1999) did not provide any statistical test for checking long-run relationship but it can be concluded form sign and magnitude of Error Correction Term (ECT). If it is negative and less than -2 , a long-run relationship can be established.

\section{Results and discussion}

Panel unit root test results from Table 1 suggest that in the case of Model $1 \& 2$, the Growth rate of Per Capita Net State Domestic Product (PC-NSDP), Property tax and commodity taxes are stationary at level. Gross investment and total tax revenue share to GDP are stationary at the 1st difference in all models and income tax share is also stationary at the same order.

\section{PMG model results}

We have reported MG, PMG and DFE estimation in the Tables 2 and 3. The Hausman test indicates that the PMG model is the best model for our data than to MG model. Negative and significant error correction terms in all the models show the long-run relationship in between variable. One major issue related to the tax-growth equation is the problem of endogeneity of the variables. As growth in per capita GDP is our dependent variables, there is a possibility that tax collections behave along with business cycles. Therefore, we tested the weak/strong exogeneity of the tax variables through the correlation analysis between business cycles and tax shares. Business cycles have been calculated using the Hodrick-Prescott (HP) Filter. We have found that all the tax instruments are very weakly related to the business cycles movement and thus, we conclude that variables are not truly endogenous.

The speed of adjustment in PMG model 1, 2 and 3 are 78.9\%, 78.4\% and 79.6\%, respectively. For the sake of completeness, we have reported MG and $\mathrm{DFE}^{5}$ model results also.

\footnotetext{
${ }^{5}$ Most of the coefficients of PMG and DFE are in similar range and smaller than to MG estimator. This is due to MG estimator only takes the information of each state time series to estimate long-run and short-run coefficients.
} 
But we are more concerned with the results of PMG estimator as Hausman test suggested that PMG is a better model than to MG. The sign of the property tax is positive and significant in the long run as well as in the short run. Results are in line with the findings of Acosta-Ormaechea and Yoo (2012). Property tax generally considered a good revenue source for state and municipal governments for providing economic and social services in the city. This tax is also able to establish cost-benefit linkages and feasible decisions for the citizens. The positive impact of property taxes indicates that the revenue generation and productive utilization of these revenues exceed the distortionary effect in these states. As we expected, the tax burden is negatively associated with growth performance in both long run and short run. The relationship is showing the distortionary effect of the tax collection in the state economy. In all models, gross investment enhancing the growth in per capita SDP in the long run. Signs are readily justified as enlargement of capital formation has a positive impact on output and employment which channelized to the development outcomes (Swan 1956, Solow 1956).

Commodity and service taxes are negatively related to the growth in per-capita SDP in the long run as well as in short run and findings are similar to the work of Ojede and Yamarik (2012). ${ }^{6}$ This tax now comes under the Goods \& Services taxes, but in the pre-GST period, commodity and service taxes are reducing growth in per capita NSDP. Commodity taxes are indirect taxes and state own tax revenues mostly come from indirect taxes. As indirect taxes, it has certain disadvantages like inflationary pressure in the economy and regressive to the poor section of the society. Our results also support the same hypothesis that increased commodity tax share is harmful. In India, commodity and service tax includes central sale tax, state excise duty, vehicle tax, goods \& passenger tax, electricity duty and entertainment tax. Central sale tax was imposed on interstate trade of commodities which is now transformed to Inter-State GST (IGST). According to Das (2017), if the IGST rate is high to the Revenue Neutral Rate, it will harm the aggregate demand in the economy through the reduction of disposable income. Heavy vehicle and passenger tax collections are creating an abysmal environment for industrial activities. The tax burden variable is also carrying a negative sign in both long run and short run and magnitude is very similar to model 1. Income tax share has become insignificant and positive in the long run and negative insignificant in the short run.

After examining the linear relationships, we extended our analysis to the examination of a non-linear relationship with the use of PMG estimation model. The result from Tables 4 and 5 indicates the existence of a non-linear relationship between tax structure and growth performance for Indian states. The linear coefficient for property taxes has now become negative and the square of it turns out to be positive. Thus, the property taxes show a 'U'-shaped relationship with states' growth performance which implies that a rise in property taxes is bad for growth initially and after a threshold point, it becomes growth enhancing. The threshold point for property taxes is 1.88 which indicates that more than $80.77 \%$ observation is more than to threshold point.

In the case of commodity and service taxes, both the linear and non-linear coefficients are significant with different signs. However, the coefficient magnitudes are abnormally

6 They use sale tax, where our study takes aggregate revenue for commodity and services. However, inference can be drawn as sale tax and is one of the dominant contributors in total commodity and service tax revenue in India. 
large and this is due to the inclusion of both linear and quadratic terms into the single equation. The small commodity and service taxes are very bad for the state economy, whereas the large amount of it shows a positive relation. The threshold point for this tax is 4.45 which implies that $79.95 \%$ observation lies above the threshold. This is a very interesting result as high commodity and service taxes could lead to high inflation in the economy and high inflation regarded as atrocious for growth. Further investigation of these findings is highly recommendable. As like linear panel regression, the income tax shows no relation in our non-linear regression model also. However, the short-run coefficient for income tax is significant and shows a negative relationship. Income tax is considered to be distortionary tax to the economy in the presence of income and substitution effect (Kotlan 2011). Income tax mostly impacts the savings of the households and labour supply which is regarded as an engine of growth.

\section{Conclusions and recommendations}

In this study, we try to find out the long-run and short-run relationship between different tax structure and economic growth in states of India. Empirical evidence from linear regression suggests that the property tax enhancing growth and commodity \& service taxes reduce it. The non-linear regression validates these findings for property taxes where high property taxes are good for growth. In the case of commodity \& service taxes, the results become opposite after the threshold point and affecting the growth negatively. Interestingly, we do not find any significant impact of income taxes on growth in both linear and non-linear regressions in the long run.

As far as the total tax burden is concerned, negative relation with the growth performance is verified and results are in line with Arnold et al. (2011). The negative effect of commodity and service taxes in the short run is expected to be neutralized through the implementation of GST in India. Promotion of growth performance at the state level concerning income taxes is also very crucial. Income tax has a direct effect on individuals and their saving and investment behaviour. On the other side, tax revenues should be placed in productive investments. With the spending, the government can promote inclusive growth, equality and efficiency in the economy.

The most promising path emerged through this study for long-run growth performance in Indian states is to lower the total tax burden and shifting from income and commodity taxes to property tax for revenue generations. The conclusion may be debatable on various grounds as the studied variables do not take into account institutional quality, administrative efficiency in tax collection, fiscal balance and condition of the states and existence of informal sectors. Future research can be done to incorporate these issues.

Abbreviations

NSDP: Net state domestic product; GST: Goods and service tax; FDI: Foreign direct investments; MG: Mean group; PMG: Pool mean group; DFE: Dynamic fixed effect; ARDL: Auto-regressive distributed lag; OECD: The organization for economic co-operation and development.

Acknowledgements

Authors like to acknowledge the anonymous referee for his/her valuable comments.

Authors' contributions

Both the authors' handled the data, analysed and contribute their part to write the manuscript. Both authors read and approved the final manuscript. 


\section{Funding}

Not applicable.

Availability of data and materials

Dataset analysed in this study is available from the corresponding author on reasonable request.

Competing interests

The authors declare that they have no competing interests.

\section{Appendix}

See Tables 1, 2, 3, 4 and 5.

Table 1 Unit root tests summary

\begin{tabular}{lllll}
\hline Variable & Deterministic trend & LLC & IPS & $\begin{array}{l}\text { Order } \\
\text { of integration }\end{array}$ \\
\hline (a) Model 1 and model 2 & & & & \\
Per capita SDP & Constant & $-10.6203^{\mathrm{a}}$ & $-10.5259^{\mathrm{a}}$ & I (0) \\
Gross investment & Constant & $-19.0118^{\mathrm{a}}$ & $-19.6703^{\mathrm{a}}$ & I (1) \\
Property tax & Constant & $-2.74745^{\mathrm{a}}$ & $-3.30371^{\mathrm{a}}$ & I (0) \\
Commodity tax & Constant & $-3.46285^{\mathrm{a}}$ & $-3.93331^{\mathrm{a}}$ & I (0) \\
Total-GDP & & $-14.6218^{\mathrm{a}}$ & $-13.8253^{\mathrm{a}}$ & I (1) \\
(b) Model 3 & & & & \\
Per Capita SDP & Constant & $-8.16398^{\mathrm{a}}$ & $-7.40650^{\mathrm{a}}$ & I (0) \\
Gross investment & Constant & $-1.38211^{\mathrm{a}}$ & $-2.43668^{\mathrm{a}}$ & I (1) \\
Property tax & Constant & $-11.5885^{\mathrm{a}}$ & $-12.6705^{\mathrm{a}}$ & I (1) \\
Total-GDP & Constant & $-10.8237^{\mathrm{a}}$ & $-10.0785^{\mathrm{a}}$ & I (1) \\
\hline
\end{tabular}

Statistically significant at $1 \%$ level. With due concern to limited space, we only reported LLC and IPS test results

Table 2 Long-run coefficients

\begin{tabular}{|c|c|c|c|c|c|c|c|c|c|}
\hline Variable & MG & PMG & DFE & MG & PMG & DFE & MG & PMG & DFE \\
\hline $\begin{array}{l}\text { Gross } \\
\text { invest- } \\
\text { ment }\end{array}$ & $\begin{array}{l}0.513 \\
\quad(0.314)\end{array}$ & $\begin{array}{l}0.152 \\
\quad(0.087)^{c}\end{array}$ & $\begin{array}{l}0.221 \\
\quad(0.115)\end{array}$ & $\begin{array}{l}0.608 \\
\quad(0.362)^{c}\end{array}$ & $\begin{array}{l}0.175 \\
(0.085)^{b}\end{array}$ & $\begin{array}{l}0.220 \\
(0.103)^{b}\end{array}$ & $\begin{array}{l}0.149 \\
\quad(0.413)\end{array}$ & $\begin{array}{l}0.399 \\
\quad(0.155)^{b}\end{array}$ & $\begin{array}{l}0.378 \\
\quad(0.125)^{\mathrm{a}}\end{array}$ \\
\hline $\begin{array}{l}\text { Property } \\
\text { tax }\end{array}$ & $\begin{array}{r}-0.098 \\
(0.415)\end{array}$ & $\begin{array}{l}0.216 \\
\quad(0.130)^{c}\end{array}$ & $\begin{array}{l}0.257 \\
\quad(0.157)\end{array}$ & & & & & & \\
\hline $\begin{array}{l}\text { Commod- } \\
\text { ity and } \\
\text { service } \\
\text { tax }\end{array}$ & & & & $\begin{array}{l}5.076 \\
(7.026)\end{array}$ & $\begin{array}{l}-2.378 \\
(0.969)^{b}\end{array}$ & $\begin{array}{l}-2.089 \\
(1.136)^{c}\end{array}$ & & & \\
\hline $\begin{array}{c}\text { Income } \\
\text { tax }\end{array}$ & & & & & & & $\begin{array}{l}0.068 \\
\quad(0.119)\end{array}$ & $\begin{array}{l}0.125 \\
\quad(0.087)\end{array}$ & $\begin{array}{l}0.130 \\
\quad(0.019)^{\mathrm{a}}\end{array}$ \\
\hline Total tax & $\begin{array}{l}0.059 \\
\quad(0.131)\end{array}$ & $\begin{array}{c}-0.041 \\
(0.024)^{c}\end{array}$ & $\begin{array}{c}-0.061 \\
(0.031)^{c}\end{array}$ & $\begin{array}{l}0.175 \\
\quad(0.213)\end{array}$ & $\begin{array}{c}-0.042 \\
(0.024)^{c}\end{array}$ & $\begin{array}{c}-0.057 \\
(0.032)^{c}\end{array}$ & $\begin{array}{r}-0.085 \\
(0.183)\end{array}$ & $\begin{array}{r}-0.013 \\
(0.033)\end{array}$ & $\begin{array}{r}-0.004 \\
(0.019)\end{array}$ \\
\hline $\begin{array}{l}\text { Hausman } \\
\text { test }\end{array}$ & & $\begin{array}{l}1.11 \\
(0.775)\end{array}$ & & & $\begin{array}{l}1.20 \\
(0.752)\end{array}$ & & & $\begin{array}{l}-0.97 \\
(0.710)\end{array}$ & \\
\hline
\end{tabular}

a, b, c Statistically significant at 1\%, 5\% and 10\% level. Parenthesis values represent standard errors and for Hausman test; it indicates probability values 


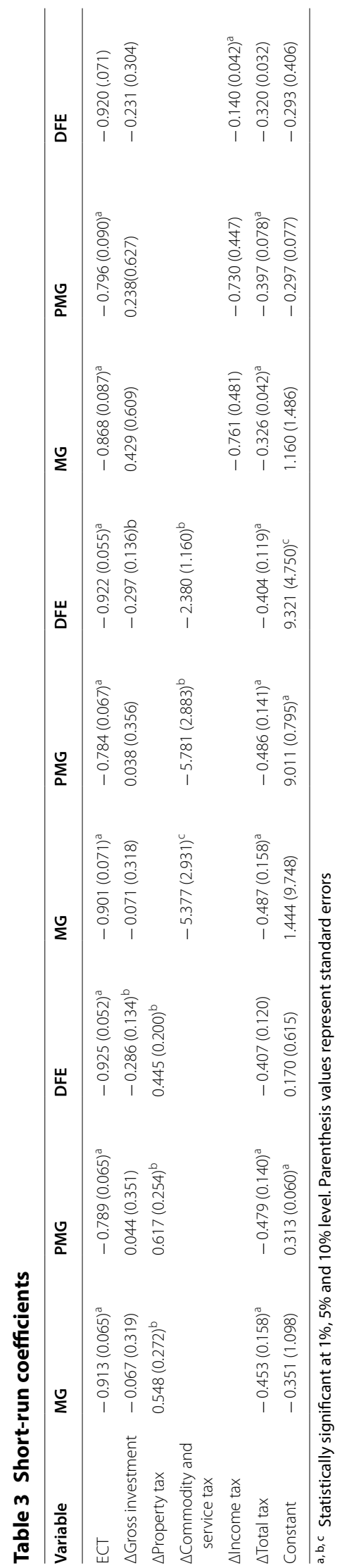


Table 4 Long-run coefficients with non-linear tax share

\begin{tabular}{llll}
\hline Variable & PMG & PMG & PMG \\
\hline Gross investment & $0.224051(0.0821584)^{\mathrm{a}}$ & $0.094958(0.0868484)$ & $0.3753215(0.1517049)^{\mathrm{b}}$ \\
Property tax & $-1.718452(0.5895772)^{\mathrm{a}}$ & & \\
Property tax square & $0.4562078(0.1350524)^{\mathrm{a}}$ & & \\
Commodity and service tax & & $-147.4204(79.33938)$ & \\
$\begin{array}{l}\text { Commodity and service tax } \\
\quad \text { square }\end{array}$ & $16.5764(8.948564) \mathrm{c}$ & \\
Income tax & & & $0.176142(0.1210151)$ \\
Income tax square & 1.88 & 4.45 & $-0.021296(0.0364334)$ \\
Inflection point & $-0.0471619(0.022339)^{\mathrm{a}}$ & $-0.0255878(0.0251895)$ & $-0.0129363(0.0352006)$ \\
Total tax & & & Nil \\
\hline
\end{tabular}

$a, b, c$ Statistically significant at $1 \%, 5 \%$ and $10 \%$ level

Parenthesis values represent standard errors

\section{Table 5 Short-run coefficients with non-linear tax share}

\begin{tabular}{llll}
\hline Variable & PMG & PMG & PMG \\
\hline ECT & $-0.8242303(0.0717583)^{\mathrm{a}}$ & $-0.7888876(0.0821668)^{\mathrm{a}}$ & $-0.7800174(0.0681541)^{\mathrm{a}}$ \\
$\Delta$ Gross investment & $0.1592222(0.4921129)$ & $0.2745088(0.5302855)$ & $0.2811591(0.6630748)$ \\
$\Delta$ Property tax & $-2.116106(4.713266)$ & & \\
$\Delta$ Property square & $0.5686091(1.021535)$ & & \\
$\Delta$ Commodity and service tax & & $318.9759(907.5429)$ & \\
$\Delta$ Commodity and service tax & & $35.24699(101.3654)$ & \\
$\quad$ square & & & $-0.8561427(0.4653239)^{\mathrm{c}}$ \\
Income tax & & & $-0.3051065(0.3196064)$ \\
$\Delta$ Income tax square & $-0.4890089(0.1418758)^{\mathrm{a}}$ & $-0.5220011(0.1608558)^{\mathrm{a}}$ & $-0.3763829(0.0905942)^{\mathrm{a}}$ \\
$\Delta$ Total tax & $1.762391(0.181032)^{\mathrm{a}}$ & $259.262(27.01652)$ & $-0.2664172(0.0755352)^{\mathrm{a}}$ \\
Constant & &
\end{tabular}

a, b, c Statistically significant at 1\%,5\% and 10\% level. Parenthesis values represent standard errors

Received: 26 November 2019 Revised: 16 March 2020 Accepted: 29 April 2020

Published online: 09 May 2020

\section{References}

Anderson TW, Hsiao C (1981) Estimation of dynamic models with error components. J Am Stat Assoc 76(375):598-606 Anderson TW, Hsiao C (1982) Formulation and estimation of dynamic models using panel data. J Econom 18(1):47-82 Arellano M, Bond S (1991) Some tests of specification for panel data: monte carlo evidence and an application to employment equations. Rev Econ Stud 58(2):277-297

Arnold JM et al (2011) Tax policy for economic recovery and growth. Econ J 121:59-80. https://doi.org/10.111 1/j.1468-0297.2010.02415.x

Atems B (2015) Another look at tax policy and state economic growth: the long and short run of it. Econ Lett 127(1):64-67

Barro RJ (1990) Government spending in a simple model of endogenous growth. J Politic Econ Univ Chicago Press 98(5):103-126

Barro RJ, Redlick CJ (2009) Macroeconomic effects from government purchases and taxes, ADB economics working paper series, No. 232

Bird RM, Zolt EM (2011) Dual income taxation: a promising path to tax reform for developing countries. World Dev 39(10):1691-1703

Choi I (2001) Unit root tests for panel data. J Int Money Fin. 20:249-272

Dackehag M, Hansson A (2012) Taxation of income and economic growth : an empirical analysis of 25 rich OECD countries

Das S (2017) Some concerns regarding the goods and services tax. Econ Polit Wkly 52(9)

Dladla K, Khobai H (2018) The impact of taxation on economic growth in South Africa, MPRA Paper No. 86219, 1-15 
Durusu-çiftçi D, Gökmenoğlu KK, Yetkiner H (2018). The heterogeneous impact of taxation on economic development: new insights from a panel cointegration approach. Economic systems. Elsevier BV. https://doi.org/10.1016/j.ecosy s.2018.01.001

Federici D, Parisi V (2015) Do corporate taxes reduce investments? Evidence from Italian firm level panel data. Cogent Econ Finance 3:1-14. https://doi.org/10.1080/23322039.2015.1012435

Gemmell N, Kneller R, Sanz I (2011) The timing and persistence of fiscal policy impacts ongrowth: evidence from OECD countries. Econ J 121(550):33-58

Im KS, Pesaran MH, Shin Y (2003) Testing for unit roots in heterogeneous panels. J Econometrics. 115:53-74

Johansson Å et al (2008) Taxation and economic. Growth. https://doi.org/10.1787/241216205486OECD

Jones L, Manuelli R, Rossi P (1993) Optimal taxation in models of endogenous growth. J Polit Econ 101(3):485-517

Karras $G$ (1999) Taxes and growth: testing the neoclassical and endogenous growth models. Contemporary Econ Policy. 17(2):177-188

King R, Rebelo S (1990) Public policy and economic growth: developing neoclassical implications. J Polit Econ 98(5):S126-50

Kotlán I, Machová Z, Janíčková L (2011) Vliv zdanění na dlouhodobý ekonomický růst. Politická ekonomie. 5:638-658

Lee Y, Gordon RH (2005) Tax structure and economic growth. J Public Econ 89(5-6):1027-1043. https://doi.org/10.1016/j. jpubeco.2004.07.002

Levin A, Lin CF, Chu CS (2002) Unit root tests in panel data: asymptotic and finite-sample properties. J Econometrics. 108(1):1-24

Ljungqvist A, Smolyansky M (2016). To cut or not to cut? On the impact of corporate taxes on employment and income, Finance and economics discussion series 2016-006. Washington: Board of Governors of the Federal Reserve System, http://dx.doi.org/10.17016/FEDS.2016.006

Macek R (2014) The impact of taxation on economic growth: case study of OECD countries. Rev Econ Perspect. 14(4):309-328. https://doi.org/10.1515/revecp-2015-0002

Maddala GS, Wu S (1999) A comparative study of unit root tests with panel data and a new simple test. Oxford Bull Econ Stat 61:631-652

Martin R, Fardmanesh M (1990) Fiscal variables and growth: a cross-sectional analysis. Public Choice 64:239-251

Mcnabb K (2018) Tax structures and economic growth: new evidence from the government revenue dataset. J Int Dev 30:173-205. https://doi.org/10.1002/jid.3345

Mdanat MF et al (2018) Tax structure and economic growth in Jordan, 1980-2015. EuroMed J Bus 13(1):102-127. https:// doi.org/10.1108/EMJB-11-2016-0030

Myles GD (2000) Taxation and economic growth. Fiscal Studies. 21(1):141-168. https://doi.org/10.1016/02649993(93)90021-7

Ojede A, Yamarik S (2012) Tax policy and state economic growth : the long-run and short-run of it, Economics Letters. Elsevier BV, 116, No.2, pp. 161-165. https://doi.org/10.1016/j.econlet.2012.02.023

Ormaechea AS, Yoo J (2012) Tax composition and growth: a broad cross-country perspective. IMF Working Papers. https ://doi.org/10.5089/9781616355678.001

Padovano F, Galli E (2001) Tax rates and economic growth in the OECD countries (1950-1990). Econ Inq 39(1):44-57

Pesaran MH, Smith RP (1995) Estimating long-run relationships from dynamic heterogeneous panels. J Econometrics. 68:79-113

Pesaran MH, Shin Y, Smith RP (1999) Pooled mean group estimation of dynamic heterogeneous panels. J Am Stat Assoc. 94:621-634

Poulson BW, Kaplani JG (2008) State income taxes and economic growth. Cato J 28(1):53-71

Rao MGR, Rao RK (2006) Trends and issues in tax policy and reform in India. INDIA POLICY FORUM

Reynolds S (2006) The impact of increasing excise duties on the economy. Working Paper Series 58069. PROVIDE Project

Saafi S, Mohamed MBH, Farhat A (2017) Untangling the causal relationship between tax burden distribution and economic growth in 23 OECD countries: fresh evidence from linear and non-linear Granger causality. Eur J Comp Econ. 14(2):265-301

Solow RM (1956) A contribution to the theory of economic growth. Q J Econ 70(1):65-94

Stoilova D (2017) Tax structure and economic growth: evidence from the European Union. Contaduría y Administración. 62:1041-1057. https://doi.org/10.1016/j.cya.2017.04.006

Stokey NL, Rebelo S (1995) Growth effects of flat-rate taxes. J Polit Econ 103(3):519-550

Swan TW (1956) Economic growth and capital accumulation. Econ Record 32:334-361. https://doi. org/10.1111/j.1475-4932.1956.tb00F434

Szarowska I (2014) Effects of taxation by economic functions on economic growth in the European Union. MPRA Paper No. 59781

Tosun MS, Abizadeh S (2005) Economic growth and tax components: an analysis of tax changes in OECD. Appl Econ 37:2251-2263. https://doi.org/10.1080/00036840500293813

Vartia L (2008) How do taxes affect investment and productivity? An industry-level analysis of OECD countries. OECD Economics Department Working Papers 656

Xing J (2011) Does tax structure affect economic growth? Empirical evidence from OECD countries, Centre for Business Taxation, WP $11 / 20$

\section{Publisher's Note}

Springer Nature remains neutral with regard to jurisdictional claims in published maps and institutional affiliations. 